\title{
The Effects of Locally Produced Phytase Enzyme on Performance and Egg Quality Characteristics of Laying Hens
}

\author{
Engin Yenice $^{1, a, *}$, Deniz Karasu ${ }^{2, b}$, Serdar Kamanlı, \\ ${ }^{1}$ Department of Animal Science, Faculty of Agriculture, Ankara University, 06110 Ankara, Turkey \\ ${ }^{2}$ Karasugen Biotechnology 34235, İstanbul, Turkey \\ ${ }^{3}$ Poultry Research Institute, Republic of Turkey Ministry of Agriculture and Forestry, 06170 Ankara, Turkey \\ *Corresponding author \\ A R T I C LE I N F O \\ Research Article \\ Received : 05/05/2020 \\ Accepted : 10/06/2020 \\ Keywords: \\ Phytase \\ Laying hen \\ Performance \\ Egg quality \\ Available phosphorus

\section{A B S T R A C T} \\ This research was conducted to determine the effect of phytase enzyme locally produced using \\ recombinant DNA technology in Turkey compare to a commercial phytase enzyme on the \\ performance and egg quality characteristics of laying hens. At the age of 40 weeks, a total of 80 \\ ATAK-S hybrid brown laying hens were distributed randomly into individual cages with 4 groups \\ and 20 repetitions (one hen in each repeat). The experiment was continued for 15 weeks. Trial \\ groups; control $(0.35 \%$ available $\mathrm{P})(\mathrm{PK})$, negative control $(0.25 \%$ available $\mathrm{P})(\mathrm{NK}), \mathrm{NK}+600$ \\ FTU / kg feed experimental phytase (DF) and NK + 600 FTU / kg feed commercial phytase (TF). \\ Reducing the available phosphorus (YP) ratio in the diet and the addition of commercial or \\ experimental phytase did not affect performance parameters such as live weight, egg yield, weight \\ and mass, feed consumption and feed conversion ratio. Egg quality characteristics as broken and \\ cracked egg ratio, eggshell weight ratio, eggshell thickness and breaking strength, albumen height \\ and Haugh unit were not affected significantly by different treatments. As a result, the effects of \\ experimental phytase locally produced on performance parameters and egg quality characteristics \\ of laying hen were similar to commercial phytase.
}

Tavukçuluk Araştırma Dergisi 17(1): 1-7, 2020

\section{Yerli Üretilen Fitaz Enziminin Yumurta Tavuklarının Performans ve Yumurta Kalite Özellikleri Üzerine Etkileri}

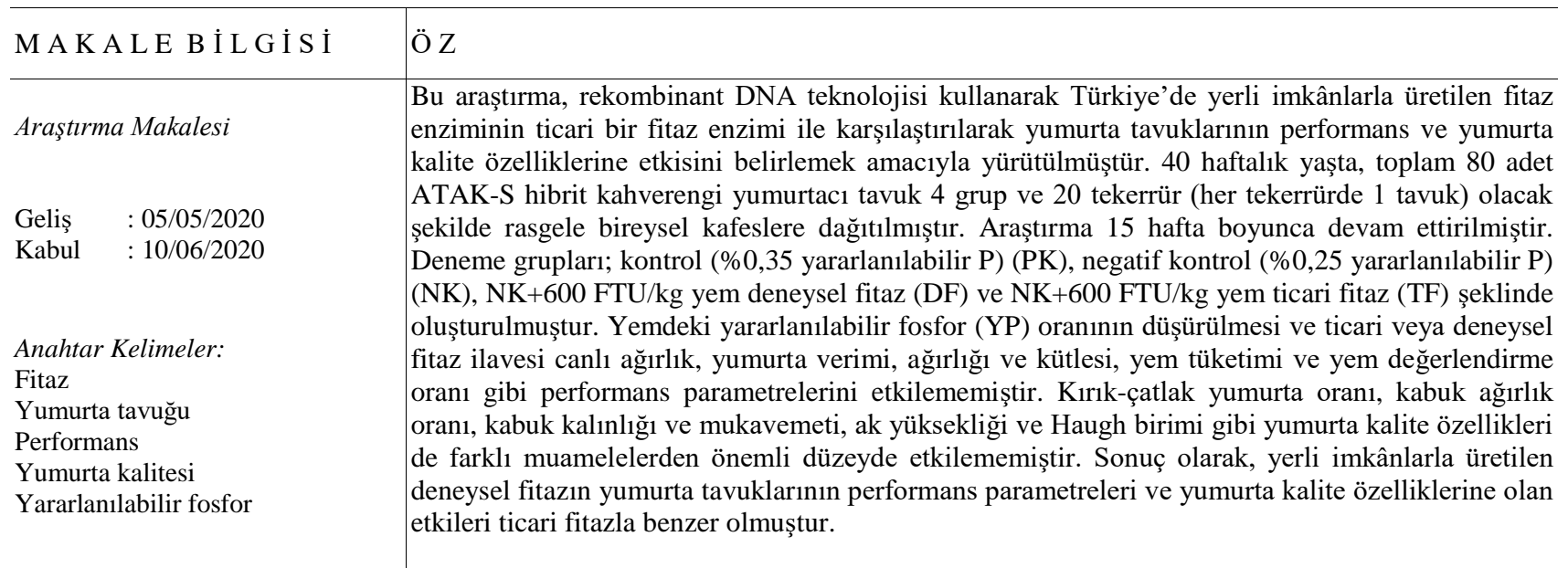




\section{Giriş}

Moleküler genetik, mikrobiyoloji ve fermantasyon teknolojilerinde meydana gelen ilerlemeler, enzim üretimi teknolojileri ve kullanım alanlarında çok büyük gelişmeler sağlamıştır. Günümüzde enzimler; gıda, tekstil, deterjan ve yem sanayinde yaygin olarak kullanılmaktadır. Global endüstriyel enzim pazarı milyar dolar ölçeğinde ve her yıl büyüyen bir pazardır ve bu pazarın yarısından fazlasını fitaz enzimi oluşturmaktadır. $\mathrm{Bu}$ potansiyele karşllık yerli bir enzim üreticisi küçük ölçekte dahi olsa yoktur ve ihtiyacın tamamı ithalat yolu ile karşılanmaktadır. Günümüzde fosfor yarayışlılığını artırmada inorganik fosfor kaynaklarına göre çok daha ekonomik olması ve fitatın anti-besinsel etkilerini azaltma açısından kanatlı yemlerinin hemen hemen tamamında fitaz enzimi kullanımı standart bir uygulama haline gelmiştir (Çiftçi, 2017).

Fosfor iskelet sisteminin gelişimi, kemik bütünlüğünün sağlanması, protein ve enerji metabolizmasındaki görevleri ile kanatlı hayvanların beslenmesinde önemli bir yere sahiptir. Kanatlı yemlerinin başlıca hammaddelerini oluşturan tahıl ve yağlı tohumlarda fosfor, fitik asit (myoinositol 1,2,3,4,5,6-hekza-dihidrojen fosfat) ve bunun tuzları olan fitatlar şeklinde depo edilmektedir. Bitkisel kökenli yem hammaddelerindeki toplam fosforun yaklaşık olarak üçte ikisi fitat fosforu şeklindedir (Eeckhout ve Paepe, 1994; Dorozhkin ve Epple, 2002). Kanatlı hayvanların fitat fosforunu hidrolize eden endojen fitaz enzimini üretme yetenekleri oldukça düşük olduğundan, bitkisel kökenli yem hammaddelerindeki fosfordan yeterince yararlanamazlar (Abudabos, 2012). Fitat fosforun önemli bir kısmı gübre ile dışarı atılmakta ve çevre kirliliğine neden olmaktadır (Mohamed ve ark., 2018). Ayrica fitat fosforu bazı mineraller, amino asitler ve nişasta ile kompleks bileşikler oluşturarak besin maddelerinin sindirim derecelerini düşürmektedir (Cowieson ve ark., 2004; Leyva-Jimenez ve ark., 2019). Fitik aside bağlı fosforun kanatlı hayvanlar tarafindan değerlendirilememesi, rasyona dikalsiyum fosfor (DCP) gibi pahalı inorganik fosfor kaynaklarının ilavesini zorunlu kılarak üretim maliyetlerinin artmasına neden olmaktadır (Lie ve ark., 2018). Fitaz (myo-inositol hexakisphosphate phosphohydrolase), fitik asidi, inorganik monofosfat, myo-inositol fosfat ve serbest myoinositol'e hidrolize ederek kanatlılar tarafindan değerlendirilmesini sağlamaktadır (Kerovuo, 2000). Birçok farklı kaynaktan elde edilen mikrobiyal fitaz ürünlerinin yem katkısı olarak en yaygın olarak kullanılanları Aspergillus niger (3-fitaz), Peniophora lycii (6-fitaz) ve Escherichia coli (6-fitaz) fitazlarıdır. Kanatl rasyonlarına fitaz, granül veya sıvı formda veya yüksek peletleme sıcaklığındaki $\left(>80^{\circ} \mathrm{C}\right)$ enzim denatürasyonu probleminden kaçınmak için peletleme sonrasında uygulanabilmektedir (Selle ve Ravindran, 2007).

Yararlanılabilir fosfor düzeyi standarttan \%30-40 oranında azaltılan ticari yumurtacı ve etlik piliç yemlerine fitaz ilavesi sonucu hayvanların ihtiyacı tamamen karşılanabilmekte ve yeme inorganik fosfor ilavesi çok azalmakta veya tamamen ortadan kalkmaktadır. Bu şekilde hem yemdeki mevcut fosfor kaynaklarının boşa harcanması önlenip yem maliyeti düşürülmekte, hem de çevre kirlenmesi azaltılmaktadır. Fitazın fitin fosforunu parçalayarak yemdeki fosfor yararlanımını (Ingelmann ve ark., 2019) artırmasının yanı sira yemdeki aminoasitler (Dersjant-Li ve Kwakernaak, 2019), nişasta (Truong ve ark., 2015), yağ ve yağ asitleri (Mohamed ve ark., 2018) ile bazı makro ve mikro elementlerin $(\mathrm{Ca}, \mathrm{Mg}, \mathrm{Fe}, \mathrm{Cu}, \mathrm{Zn})$ sindirilebilirliğini (Sebastian ve ark., 1996; Leyva-Jimenez ve ark., 2019) de artırdığı yapılan çalışmalarla gösterilmiştir Zira fitat fosforu protein, peptitler ve bazı katyonlar ile kompleks bileşikler oluşturma eğiliminde olup bazı endojen enzimleri de kendisine bağlayarak etkisiz hale getirme kabiliyetine sahiptir (Mohamed ve ark., 2018).

$\mathrm{Bu}$ araştırmanın amacı, rekombinant DNA teknolojisi kullanarak Türkiye'de yerli imkânlarla üretilen fitaz enziminin ticari bir fitaz enzimi ile karşılaştırılarak, yumurta tavuklarının performans ve yumurta kalite özelliklerine etkisini belirlemek ve yerli fitazın etkinliğini test etmektir.

\section{Materyal ve Yöntem}

Deneysel fitaz üretiminde kullanılan suş Aspergillus niger CBS 513.88 suşudur. Buna klonlanan gen ise Aspergillur niger phyA (Uniprot P34752) fitaz genidir. $\mathrm{Bu}$ phya geni Glucoamylase promoter ile sürekli indüklenerek üretilmektedir. Fitaz üretimi için A. niger suşlarından flask ölçekte fitaz aktivite taraması yapılarak en yüksek fitaz aktivitesine sahip suşun tespiti yapılmıştır (Choi ve ark., 2001). Tespit edilen suş için fermantasyon besi yeri içeriği, sıcaklık, pH, çözünmüş oksijen oranı, aşılama hacmi ve miktarı, proses zamanı gibi fermantasyon parametreleri flask ve $5 / 20 \mathrm{~L}$ fermentör ölçeğinde optimize edilmiştir. Optimizasyon çalışmalarında Yanıt Yüzey Metodolojisi (Response surface methodology RSM) tekniği kullanılmıştır (Baş ve Boyacı, 2007). İlk aşamanın neticesinde 1.500 .000 ünite/L fitaz aktivitesi sağlayan biyoproses geliştirilmiş ve fitaz enzimi sıvı formda ürün haline getirilmiştir.

Deneme öncesinde bireysel kafeslere yerleştirilen toplam 200 adet ATAK-S hibrit kahverengi yumurtac1 tavuk 15 gün süreyle ticari yumurta tavuğu yemi ile yemlenerek tavukların yumurta verimleri ve yumurta ağırlıkları tespit edilip, canlı ağırlıkları belirlenmiştir. 40 haftalık yaşta, bu özellikler bakımından gruplar arasında farklılık olmamasina dikkat edilerek, toplam 80 adet tavuk tesadüf parselleri deneme tertibine uygun olarak 4 grup ve 20 tekerrür (her tekerrürde 1 tavuk) olacak şekilde rasgele bireysel kafeslere $(29 \times 50 \times 54 \mathrm{~cm})$ dağıtılmıştır. Araştırma 15 hafta boyunca devam ettirilmiş ve bu süre içerisinde yem ve su serbest olarak tavuklara verilmiştir. Deneme kümesi 1 şık ve havalandırma kontrollü olup, sabit 16 saat aydınlatma uygulanmıştır. Deneme gruplar1; kontrol (\%0,35 yararlanılabilir P) (PK), negatif kontrol (\%0,25 yararlanılabilir P) (NK), NK+600 FTU/kg yem deneysel fitaz (DF) ve NK+600 FTU/kg yem ticari fitaz (TF) şeklinde oluşturulmuştur (Çizelge 1).

Tavukların besin maddeleri ihtiyacı ATAK-S Hibrit Kataloğu (2015) bildirişi dikkate alınarak belirlenmiştir. Araştırma başlamadan önce yem hammaddelerinin, ham besin maddeleri, şeker ve nişasta analizleri AOAC (1990) da bildirilen yöntemlere göre yapılmıştır. Metabolik enerjinin hesaplanmasında Janssen (1989)'in bildirişinden yararlanılmıştır. Karma yemler elde edilen bu değerler 
kullanılarak izokalorik ve izonitrojenik olarak hazırlanmıştır. Analiz yapılmayan besin maddeleri hesaplanırken, NRC (1994)'de bildirilen değerlerden yararlanılmıştır. Normal ve düşük yararlanılabilir fosforlu deneme yemlerinin yapısı ve kimyasal bileşimi Çizelge 2 'de verilmiştir.

Çizelge 1. Deneme planı

Table 1. Experimental design

\begin{tabular}{c|l}
\hline Gruplar & \multicolumn{1}{|c}{ Uygulama } \\
\hline $\begin{array}{c}\text { Grup 1 } \\
\text { (PK) }\end{array}$ & $\begin{array}{l}\text { Normal \%0,35 yararlanılabilir fosfor, fitaz yok } \\
\text { (Pozitif kontrol) }\end{array}$ \\
\hline Grup 2 & $\begin{array}{l}\text { Düşük \%0,25 yararlanılabilir fosfor, fitaz yok } \\
\text { (Negatif kontrol) }\end{array}$ \\
\hline Grup 3 & $\begin{array}{l}\text { Düşük \%0,25 yararlanılabilir fosfor + deneysel } \\
\text { (DF) } \\
\text { fitaz (600 FTU*/kg yem) }\end{array}$ \\
\hline Grup 4 & $\begin{array}{l}\text { Düşük \%0,25 yararlanılabilir fosfor + ticari fitaz } \\
\text { (TF) }\end{array}$ \\
\hline
\end{tabular}

*FTU: $5,5 \mathrm{pH}$ ve $37^{\circ} \mathrm{C}$ ' de, sodyum fitat dan dakikada 1 mikromol inorganik fosfat ayrıştıran enzim miktarı (Choi ve ark., 2001).

Çizelge 2. Deneme yemlerinin yapısı ve kimyasal bileşimi

Table 2. Composition and chemical component of the experimental diets

\begin{tabular}{|c|c|c|}
\hline Yem hammaddeleri & PK & NK \\
\hline Misir & 52,64 & 52,91 \\
\hline Tam yağlı soya & 13,0 & 13,0 \\
\hline Soya küspesi & 5,98 & 5,75 \\
\hline Ayçiçeği tohumu küspesi & 11,71 & 11,96 \\
\hline Misır glüten unu & 4,0 & 4,0 \\
\hline Bitkisel yağ & 1,5 & 1,42 \\
\hline Mermer tozu & 8,92 & 9,30 \\
\hline Di kalsiyum fosfat & 1,30 & 0,71 \\
\hline Tuz & 0,35 & 0,35 \\
\hline DL-Metiyonin & 0,10 & 0,10 \\
\hline Kolin & 0,10 & 0,10 \\
\hline Vitamin ön karma ${ }^{1}$ & 0,10 & 0,10 \\
\hline Mineral ön karma² & 0,10 & 0,10 \\
\hline Salmonella önleyici & 0,20 & 0,20 \\
\hline Toplam & 100 & 100 \\
\hline \multicolumn{3}{|c|}{ Kimyasal kompozisyon } \\
\hline Ham protein $(\%)$ & 18,0 & 18,0 \\
\hline Metabolik enerji (kcal/kg) & 2750 & 2750 \\
\hline Kuru madde $(\%)$ & 88,53 & 88,50 \\
\hline Ham selüloz (\%) & 5,09 & 5,14 \\
\hline Ham yağ (\%) & 6,19 & 6,12 \\
\hline Kalsiyum $(\%)^{3}$ & 3,75 & 3,75 \\
\hline Yaralanılabilir fosfor $(\%)^{3}$ & 0,35 & 0,25 \\
\hline Metiyonin $(\%)^{3}$ & 0,43 & 0,43 \\
\hline Metiyonin+Sistin $(\%)^{3}$ & 0,75 & 0,75 \\
\hline $\operatorname{Lizin}(\%)^{3}$ & 0,74 & 0,73 \\
\hline Triptofan $(\%)^{3}$ & 0,17 & 0,17 \\
\hline Linoleik asit $(\%)^{3}$ & 3,37 & 3,33 \\
\hline
\end{tabular}

${ }^{1}$ Vitamin ön karmanın her 1 kg'1 $15000000 \mathrm{IU}$ A, 5.000.000 IU D $\mathrm{D}_{3}$, $50.000 \mathrm{mg} \mathrm{E}, 10.000 \mathrm{mg} \mathrm{K}_{3}, 4.000 \mathrm{mg} \mathrm{B}_{1}, 8.000 \mathrm{mg} \mathrm{B}_{2}, 5.000 \mathrm{mg} \mathrm{B}_{6}, 25$ $\mathrm{mg} \mathrm{B} \mathrm{B}_{12}, 50000 \mathrm{mg}$ niasin, $20.000 \mathrm{mg}$ pantotanik asit, $2.000 \mathrm{mg}$ folik asit, $250 \mathrm{mg}$ biotin, $75.000 \mathrm{mg}$ askorbik asit, $175.000 \mathrm{mg}$ kolin vitaminlerini içermektedir. ${ }^{2}$ Mineral ön karmanın her 1 kg'1 35.000 mg $\mathrm{Mg}, 56.000 \mathrm{mg} \mathrm{Mn}, 140.000 \mathrm{mg} \mathrm{Zn}, 56.000 \mathrm{mg} \mathrm{Fe}, 10.500 \mathrm{mg} \mathrm{Cu}, 1050$ mg I, $280 \mathrm{mg}$ Co, $280 \mathrm{mg} \mathrm{Se}, 700 \mathrm{mg}$ Mo minerallerini içermektedir. ${ }^{3} \mathrm{NRC}$ (1994) de bildirilen değerlerden yararlanılmıștır.

Karma yemler özel bir yem fabrikasında, granül formda, pastörize edilerek hazırlanmıştır. Pastörizasyon işlemi yemin $140^{\circ} \mathrm{C}$ buhar sicaklığı ve 3 bar basınç altında 4 dakika muamele edilmesiyle yapılmış, yemin sıcaklığ $\quad 85^{\circ} \mathrm{C}$ olarak ölçülmüştür. Ticari fitaz (RONOZYME® HiPhos) granül formda yeme ilave edilirken, deneysel fitaz sıvı formda karıştırıcı çalışırken yem üzerine püskürtülerek yemle karışması sağlanmıştır. Her iki fitaz da bir kg yemde 600 FTU aktivite olacak miktarda yeme ilave edilmiştir. Deneysel fitaz (DF) ve ticari fitaz (TF) gruplarının yemleri NK grubu yemine deneysel veya ticari fitaz ilavesi ile hazırlanmıştır.

Yumurta tavuklarının yumurta verimleri ve kırıkçatlak yumurta sayıları günlük olarak kaydedilmiştir. Tavukların yem tüketimleri ve yumurta ağırlıkları, her 15 günde bir yapılan tartımlarla bireysel olarak tespit edilmiştir. Yemlerin tartılmasında $10 \mathrm{~g}$ duyarlı (Oliwetti JWI-586, Jadever Scale Co. Ltd, Taiwan), yumurtaların tartılmasında 0,1 g duyarlı (Dikomsan Elektronik Ltd. Tic. San, Türkiye) teraziler kullanılmıştır. Yumurta ağırlığ1 ve yumurta verimi değerlerinden yumurta kütlesi [yumurta ağırlı̆̆ı $(\mathrm{g}) \times$ yumurta verimi $(\%) / 100$ ], yem tüketimi ve yumurta kütlesi değerlerinden yem değerlendirme sayısı [tüketilen yem miktarı (g) / yumurta kütlesi $(\mathrm{g})$ ] hesaplanmıştır. Tavukların deneme başı ve sonu canlı ağırlıkları bireysel olarak $5 \mathrm{~g}$ duyarlı tartı aleti (Waymaster, İngiltere) ile manuel olarak tespit edilmiştir.

Denemede her 15 günde, bir günlük yumurta toplanarak, toplandıktan bir gün sonra yumurta iç ve dış kalite kriterlerinden, kabuk kalınlığı ve ağırlığı, kabuk mukavemeti, yumurta ak yüksekliği ve Haugh birimi belirlenmiştir. Kabuk kalınlığı Mitutoyo dijital mikrometre (Japonya) ile ölçülmüştür. Kabuk kalınlığı değeri yumurta kabuğunun sivri, küt ve orta bölümlerinin kabuk zarı soyulduktan sonra yapılan ölçümlerinin ortalaması şeklinde hesaplanmıştır. Kırılma mukavemeti, Futura mukavemet ölçüm cihazı ile Newton cinsinden ve ak yüksekliği Futura ak ve sarı yüksekliği ölçüm ünitesi ile elektronik olarak yapılmıştır (Futura, Lohne, Germany). Haugh birimi (HB), ak yüksekliği (AY) ve yumurta ağırlığı (YA) değerleri kullanılarak aşağıdaki formüle göre Futura yumurta kalite analiz programı tarafından hesaplanmıştır (Haugh 1937).

$$
\mathrm{HB}=100 \log \left(\mathrm{AY}+7,57-1,7 \mathrm{YA}^{0,37}\right)
$$

Araştırmada yüzde olarak ifade edilen parametreler açı transformasyonuna tabi tutulmuş ve elde edilen parametreler Tesadüf Parselleri Deneme Tertibinde MINITAB 14 release paket programında değerlendirilmiş ve gruplar arasındaki farklılığın hangi gruplar arasında olduğunu tespit etmek için Duncan testinden (Duncan 1955) yararlanılmıştır.

$\mathrm{Bu}$ araştırma, Tavukçuluk Araştırma Enstitüsü Müdürlüğü Hayvan Deneyleri Yerel Etik Kurulu'nun 22.04.2016/10 sayılı kararı ile onaylanmış ve aynı kurul tarafından takip edilmiştir.

\section{Bulgular ve Tartışma}

Deneme süresince muamele gruplarında tavuk ölümü olmamıştır. Pozitif kontrol grubu ile karşılaştırıldığında, 40-55 haftalık yaşlar arasında, yemde yararlanılabilir fosfor (YP) düzeyinin düşürülmesi ( $\% 0,35$ 'den $\% 0,25$ 'e) ve deneysel veya ticari fitaz ilavesinin, deneme sonu canl ağırlık ve canlı ağırlık değişimini etkilemediği görülmektedir ( $\mathrm{P}>0,05)$ (Çizelge 3). Benzer olarak, 22-61 haftalık yaşlar arasında kahverengi yumurtacılarda (Liebert ve ark., 2005) ve 50-62 haftalık yaşlar arasında 
beyaz yumurtacilarda (Fernandez ve ark., 2019) misırsoya esaslı yemlerde YP'nin \%0,12'e düşürülmesinin ve bu yeme değişik düzeylerde fitaz veya inorganik $P$ ilavesinin canlı ağırlığı etkilemediği bildirilmiştir. Yine beyaz yumurtacılar üzerinde yapılan farklı çalışmalarda; 21-33 (Wu ve ark., 2006), 40-61 (Jalal ve Scheideler, 2001) ve 25-37 (Pongmanee ve ark., 2020) haftalık yaşlarda, YP' nin sirasıyla \%0,10\%0,26 ve \%0,22' ye düşürülmesi ile kontrol gruplarına göre canlı ağırlıkta bir olumsuzluk görülmemiştir. $\mathrm{Bu}$ çalışmalarda farklı dozlarda fitaz ilavesi canlı ağırlık üzerine etkili olmamıştır. $\mathrm{Bu}$ çalışmalardan farklı olarak, \%0,10 YP verilen beyaz yumurtacı tavuklarda, 20-60 haftalık yaşlar arasında ilk 8 hafta canlı ağırlıkta değişme olmazken, daha sonraki dönemde canlı ağırlıkta azalma olmuş, yeme fitaz ilavesi canlı ağırlıktaki düşmeyi önlemiştir (Boling ve ark., 2000). Keshavarz (2000) tarafından kahverengi yumurtacılarda 30-66 haftalarda yapılan bir çalışmada da YP oranının \%0,40 dan \%0,15 azaltilarak \%0,25'e indirilmesi canlı ağırlığı etkilemezken, \%0,20 ve \%0,15'e indirilmesi olumsuz etkilemiş, fitaz ilavesi bu olumsuzluğu önlemiştir.

Yemdeki YP oranının düşürülmesi ve ticari veya deneysel fitaz ilavesi yumurta verimi, ağırlığı ve kütlesi, yem tüketimi ve yem değerlendirme oranı gibi performans değerlerini etkilememiştir ( $\mathrm{P}>0,05)$ (Çizelge 4).

Yürütülen çalışma ile uyumlu olarak, benzer düşük YP (\%0,22 ve 0,25) oranlarının kullanıldığı iki çalışmada (Musapuor ve ark., 2005; Pongmanee ve ark., 2020), yemin YP oranının düşürülmesi ve düşük YP içeren yemlere artan dozlarda (150-1200 FTU/kg yem) fitaz ilaveleri yumurta verimini önemli düzeyde etkilememiştir. Yürütülen çalışmadan daha düşük YP (\%0,10-0,15 arasında) içeren bazı çalışmalarda (Jalal ve Scheideler, 2001; Liebert ve ark., 2005) yumurta verimi düşük YP ve enzim ilavelerinden etkilenmezken, bazı çalışmalarda ise yemdeki YP oranının fazlaca düşürülmesi (\%0,08-0,15 arasında) ile yumurta veriminin azaldığı, fitaz ilavesi ile yumurta verimindeki düşüşün önlendiği bildirilmiştir (Boling ve ark., 2000; Lim ve ark., 2003; Zyla ve ark., 2012; Fernandez ve ark., 2019). Yürütülen çalışmada olduğu gibi, mantar veya bakteriyel kaynaklı iki fitazın karşılaştırıldığı çalışmada (Wu ve ark., 2006), \%0,11 YP içeren yumurta tavuğu yemlerine farklı orjinden fitaz ilavesi yapılmış ve her iki fitazın da düşük YP den ileri gelen yumurta verimi düşüklüğünü aynı derecede önlediği bildirilmiştir. Keshavarz (2000) tarafından kahverengi yumurtacilarda 30-66 haftalarda yapılan bir çalışmada ise YP oranının \%0,40'dan \%0,15 azaltılarak $\% 0,25$ 'e indirilmesi yumurta verimini etkilemezken, $\% 0,20$ ve $\% 0,15$ 'e indirilmesi olumsuz etkilemiş, fitaz ilavesi bu olumsuzluğu önlemiştir.

Yürütülen çalışmada YP seviyesinin \%0,25'e düşürülmesiyle yumurta ağırlığında kontrol ve fitaz ilaveli gruplarla önemli farklılıkların belirlenmemesi, daha önceki benzer çalışmalarla (Jalal ve Scheideler, 2001; Liebert ve ark., 2005; Musapuor ve ark., 2005; Kubis ve ark., 2019) uyumludur. Yürütülen çalışmadan daha düşük YP oranlarının $(\% 0,08 \% 0,10$ ve \%0,12) kullanıldığı bazı çalışmalarda (Zyla ve ark., 2012; Gordon ve Roland, 1997; Fernandez ve ark., 2019) YP oranın düşürülmesi ile yumurta ağırlığında önemli düşüş belirlenirken, farklı dozlarda (300-1800 FTU/kg yem) fitaz ve inorganik fosfor ilaveleri yumurta ağırlığını önemli düzeyde arttırmıştır.

Keshavarz (2000), YP oranının \%0,40’dan \%0,25'e indirilmesi ile yürütülen çalışmada olduğu gibi yumurta kütlesinin etkilenmediğini, ancak YP nin \%0,20 ve $\% 0,15$ 'e indirilmesi ile yürütülen çalışmadan farklı olarak olumsuz etkilendiğini bildirmiştir. Farklı araştırmacılar YP nin \%0,08-0,12 oranlarına düşürülmesinin yumurta kütlesini önemli düzeyde azalttığını, ancak fitaz ilavesi ile kontrolle aynı seviyeye ulaştığını bildirilmişlerdir (Jalal ve Scheideler, 2001; Wu ve ark., 2006; Zyla ve ark., 2012; Fernandez ve ark., 2019).

Çizelge 3. Deneysel ve ticari fitazın canlı ağırlık üzerine etkisi

Table 3. The effect of experimental and commercial phytase on live weight

\begin{tabular}{c|ccc}
\hline Gruplar & $\begin{array}{c}\text { Deneme başı canlı ağırlık } \\
\text { (g/tavuk) }\end{array}$ & $\begin{array}{c}\text { Deneme sonu canlı ağırlık } \\
\text { (g/tavuk) }\end{array}$ & $\begin{array}{c}\text { Canlı ağırlık değişimi } \\
(\mathrm{g} / \text { tavuk })\end{array}$ \\
\hline PK & 1932 & 1946 & 14,0 \\
NK & 1934 & 1944 & 10,0 \\
DF & 1931 & 1947 & 16,0 \\
TF & 1931 & 1960 & 21,6 \\
\hline SEM & 11,1 & 6,32 & 12,9 \\
P & 1,0 & 0,798 & 0,992 \\
\hline
\end{tabular}

Çizelge 4. Deneysel ve ticari fitazın performans özellikleri üzerine etkisi

Table 4. The effect of experimental and commercial phytase on performance characteristics

\begin{tabular}{c|ccccc}
\hline Gruplar & $\begin{array}{c}\text { YV } \\
(\% / \text { tavuk/gün) }\end{array}$ & $\begin{array}{c}\text { YA } \\
\text { (g/yumurta) }\end{array}$ & $\begin{array}{c}\text { YK } \\
\text { (g/tavuk/gün) }\end{array}$ & $\begin{array}{c}\text { YT } \\
\text { (g/tavuk/gün) }\end{array}$ & $\begin{array}{c}\text { YYO } \\
\text { (g yem/g yumurta) }\end{array}$ \\
\hline PK & 85,18 & 60,34 & 51,47 & 123,7 & 2,422 \\
NK & 84,77 & 60,12 & 50,92 & 123,2 & 2,442 \\
DF & 84,95 & 60,68 & 51,58 & 123,6 & 2,417 \\
TF & 84,89 & 60,38 & 51,18 & 123,3 & 2,417 \\
SEM & 0,551 & 0,418 & 0,474 & 0,145 & 0,0297 \\
P & 0,999 & 0,974 & 0,963 & 0,652 & 0,981 \\
\hline
\end{tabular}


Çizelge 5. Deneysel ve ticari fitazın yumurta kalite özellikleri üzerine etkisi

Table 5. The effect of experimental and commercial phytase on egg quality characteristics

\begin{tabular}{c|cccccc}
\hline Gruplar & KÇYO & KAO & KK & KM & AY & HB \\
\hline PK & 1,27 & 11,31 & 312,4 & 33,13 & 6,79 & 81,64 \\
NK & 1,19 & 11,28 & 311,7 & 32,91 & 6,59 & 80,19 \\
DF & 1,20 & 11,18 & 313,0 & 34,04 & 6,57 & 80,14 \\
TF & 1,08 & 11,26 & 312,3 & 35,50 & 6,69 & 81,22 \\
\hline SEM & 0,145 & 0,07 & 2,23 & 0,521 & 0,091 & 0,557 \\
P & 0,945 & 0,931 & 0,998 & 0,286 & 0,834 & 0,722 \\
\hline
\end{tabular}

KÇYO: Kırık çatlak yumurta oranı (\%), KAO: Kabuk ağırlığı oranı (\%), KK: Kabuk kalınlığı (Mmm), KM: Kabuk mukavemeti (Newton), AY: Ak yüksekliği (mm), HB: Haugh birimi

Yürütülen çalışmada düşük YP $(\% 0,25)$ ve yeme deneysel veya ticari fitaz ilavesinin yem tüketimi ve yemden yararlanmayı önemli düzeyde etkilememesi, yürütülen çalışmadakine benzer YP seviyelerinin ve farklı dozlarda fitaz ilavelerinin kontrol grubuna göre yem tüketimi ve yemden yararlanmayı değiştirmediği önceki bazı çalışmalarla (Kubis ve ark., 2019; Pongmanee ve ark., 2020) uyumludur. Keshavarz (2000) tarafindan kahverengi yumurtacilarda 30-66 haftalarda yapılan bir çalışmada, YP oranının \%0,40 dan \%0,25 e indirilmesi yürütülen çalışmada olduğu gibi yem tüketimi ve yem değerlendirmeyi etkilememiş, ancak YP daha da düşürüldüğünde $(\% 0,20$ ve $\% 0,15)$ bu çalışmadan farklı olarak olumsuz etkilemiş, fitaz ilavesi bu olumsuzluğu önlemiştir. YP oranının fazlaca düşürülmesi ile yem tüketimi ve yem değerlendirmede meydana gelen kötüleşmenin, yumurta tavuğu yemlerine inorganik fosfor ve fitaz ilavesi ile önlenebildiği birçok çalışmayla gösterilmiştir (Boling ve ark., 2000; Liebert ve ark., 2005; Musapuor ve ark., 2005; Fernandez ve ark., 2019).

Pozitif kontrol ile karşılaştırıldı̆̆ında, YP düzeyinin düşürülmesi ve yeme deneysel veya ticari fitaz ilavesi kırık-çatlak yumurta oranı, kabuk ağırlık oranı, kabuk kalınlığı ve mukavemeti, ak yüksekliği ve Haugh birimini önemli düzeyde etkilememiştir $(\mathrm{P}>0,05)$ (Çizelge 5).

Yürütülen çalışma ile uyumlu olarak, kahverengi yumurtacılarda 21-41 haftalık yaşlar (Lim ve ark., 2003) arasinda YP'nin \%0,15'e, beyaz yumurtacilarda 25-37 haftalık yaşlar (Pongmanee ve ark., 2020) ve 50-62 haftalık yaşlar (Fernandez ve ark., 2019) arasında sırasıyla $\% 0,22$ ve $\% 0,12$ 'e düşürülmesi ve değişik düzeylerde fitaz veya inorganik $\mathrm{P}$ ilavelerinin yumurta kabuk mukavemetini ve kabuk kalınlığını önemli düzeyde etkilemediği bildirilmiştir. Yine 30-66 haftalık yaşlarda kahverengi (Keshavarz, 2000) ve 40-61 haftalık yaşlarda beyaz yumurtacilar (Jalal ve Scheideler, 2001) ile yapılan çalışmalarda, YP oranının yürütülen çalışmadan daha fazla (sırasıyla $\% 0,40$ 'dan $\% 0,15^{\prime}$ 'e ve $\% 0,35$ 'den $\% 0,10$ 'a kademeli olarak) düşürülmesi ve fitaz ilavesinin yumurta kabuk ağırlık oranını önemli düzeyde etkilemediği bildirilmiştir. Ayrıca, (Jalal ve Scheideler 2001), haugh biriminin de benzer uygulamalardan etkilenmediğini bildirmişlerdir.

Yürütülen çalışmadan farklı olarak bazı çalışmalarda, YP düzeyinin düşürülmesi ile kabuk ağırlık oranı (Zyla ve ark., 2012), kabuk mukavemeti ve kalınlığ1 (Zyla ve ark., 2012; Kubis ve ark., 2019), Haugh birimi (Lim ve ark., 2003) önemli düzeyde azalırken, kırık-çatlak yumurta oranının (Lim ve ark.,
2003) arttığı bildirilmiştir. Bu çalışmalarda fitaz ilavesi ile düşük fosfor seviyesinden ileri gelen olumsuzlukların önlendiği belirtilmiştir. Kis ve ark. (2000) yemde fosfor (P) ve kalsiyum $(\mathrm{Ca})$ içeriğinin azaltılması buna karşıllık fitaz ilavesi ile tavukların yumurta kabuğu kalınlığının, sağlamlığının ve kabuk $\mathrm{P}$ ve $\mathrm{Ca}$ içeriğinin korunduğunu bildirmişlerdir.

Yemdeki yararlanılabilir fosfor oranının düşürülmesi ile yürütülen çalışmada ve bazı önceki çalışmalarda $P$ yetersizliğinin ortaya çıkmaması; yemdeki YP düzeyi, yetersizliğin süresi (deneme süresi) ve fitat fosfordan yararlanmadaki farklılıklar gibi faktörlerden kaynaklanmaktadır. Fitat fosforundan yararlanma; kanatının yaşı ve genotipi, fitat kaynağı, yemdeki $\mathrm{Ca}$, vitamin $\mathrm{D}_{3}$ ve selüloz düzeyleri vb. göre değişkenlik gösterebilmektedir (Deniz, 2014). Normal şartlar altında, yumurta tavukları, yumurta kabuk oluşumu için gerekli olan $\mathrm{Ca}^{\prime} \mathrm{u}$ yemden ve medüller kemikten almaktadırlar ve bu kemik hızlı bir şekilde rezervlerini yenileme kabiliyetine sahiptir (Miller, 1992). Bununla birlikte, tavuklara yetersiz miktarda $\mathrm{P}$ verildiğinde, kalsiyum fosfatın hidroksiapatit kristallerini oluşturmak için yeterli $\mathrm{P}$ olmadığından medüller kemik döngü süreci bozulmaktadır. Tavuk tüm medüller kemik rezervlerini tükettiğinde, hem kortikal hem de trabeküler yapısal kemikleri kullanmakta ve bu kemiklerin mobilizasyonu sonucu ortaya çıkan $\mathrm{P}$ ile uzun süre $\mathrm{P}$ ihtiyacını, performans ve yumurta kalite parametreleri azalmadan karşılayabilmektedir. Kemik yapısının bir parçası olma rolünün yanı sıra $\mathrm{P}$, hemen hemen tüm metabolik olaylarda yer alan organik bileşiklerin önemli bir bileşenidir ve bu nedenle $\mathrm{P}$ eksikliği, iskelet problemlerinin yanı sira enerji metabolizmasinın ve protein sentezinin bozulmasına neden olmaktadır. Fosfor yetersizliğinin devam etmesi halinde, yumurta tavuğu artık üretimini koruyamamakta veya metabolik fonksiyonlarını sürdürememektedir (Fernandez ve ark., 2019). Bu bölümde birçok çalışmada belirtildiği gibi düşük YP içeren yemlere fitaz ilavesi, fitat fosfordan yararlanım sağlayarak performans ve yumurta kalitesinin bozulmasını engellemiştir. Ancak fitaz etkinliğinde; yeme, fitaz enzimine ve hayvana ait faktörler olmak üzere, yemin sindirim sisteminde kalış süresi, yemin ve sindirim sistemi içeriğinin $\mathrm{pH}$ ', metal iyonlarının varlığı, fitat substratı yoğunluğu ve karakteri, yeme katılan organik asitler, toksin bağlayıcılar, anti-bakteriyel yem katkıları, yemin $\mathrm{Ca}$, toplam $\mathrm{P}$ ve vitamin $\mathrm{D}_{3}$ içeriği ve $\mathrm{Ca} / \mathrm{P}$ oranı, fitaz dozu, fitaz kaynağı (3 veya 6 -fitaz olması durumu), kanatlının yaşı, verim yönü vb. çok sayıda faktör etkili olmaktadır (Çiftçi, 2017). 


\section{Sonuç}

Yerli imkânlarla üretilen deneysel fitazın yumurta tavuklarının performans parametreleri ve yumurta kalite özelliklerine olan etkileri ticari fitazla benzer olmuştur. Bundan sonraki yerli fitaz çalışmalarında ticarileşmeye geçebilmek adına, 1.500.000 ünite/L olan üretim aktivite düzeyinin ve termostabilitesinin artırılması, toz ve granül formda üretimin de yapılması yönünde $\mathrm{Ar}-\mathrm{Ge}$ çalışmalarına devam edilmesi gerekmektedir.

\section{Teşekkür}

Bu çalışma T.C. Tarım ve Orman Bakanlığ 1 Tarımsal Araştırmalar ve Politikalar Genel Müdürlüğü (TAGEM) tarafindan Araştırma-Geliştirme Destek Programı kapsamında TAGEM/16/AR-GE/39 numaralı Araştırma Projesi olarak desteklenmiştir.

\section{Kaynaklar}

Abudabos, A.M. 2012. Intestinal phytase activity in chickens (Gallus domesticus). Afr J Microbiol Res., 6: 4932-4938.

ATAK-S Hibrit Kataloğu. 2015. Tavukçuluk Araştırma Enstitüsü Müdürlüğü, 3. Basım, Reproton Reprodüksiyon Ltd. Şti, Ankara.

Baş D., Boyac1, İ.H. 2007. Modeling and optimization I: Usability of response surface methodology. Journal of Food Engineering, 78 (3): 836-845. doi:10.1016/j.jfoodeng. 2005.11.024

Boling S., Douglas M., Shirley R., Parsons C.M., Koelkebeck K.W. 2000. The effects of various dietary levels of phytase and available phosphorus on performance of laying hens. Poultry Science, 79: 535-538.

Choi Y.M., Suh H.J., Kim J.M. 2001. Purification and properties of extracellular phytase from Bacillus sp. KHU-10. Journal of Protein Chemistry, 20: 287-292.

Çiftçi, İ. 2017. Broyler yemlerinde enzim uygulama tecrübeleri ve pratik uygulama stratejileri, 4 th International Poultry Meat Congress, page:140-144, 26-30 Nisan, Antalya/ Türkiye.

Cowieson, A.J., Acamovic, T., Bedford, M.R. 2004. The effects of phytase and phytic acid on the loss of endogenous amino acids and minerals from chickens. Br. Poult. Sci., 45: 101-108.

Deniz, G. 2014. Kanatlı hayvanların rasyonlarında fitaz enzimi kullanılmasının önemi. Uludag Univ. J. Fac. Vet. Med., 33 $(1,2): 27-31$.

Dersjant-Li, Y., Kwakernaak, C. 2019. Comparative effects of two phytases versus increasing the inorganic phosphorus content of the diet, on nutrient and amino acid digestibility in boilers. Animal Feed Science and Technology, 253: 166180, doi:10.1016/j.anifeedsci.2019.05.018

Dorozhkin, S.V., Epple, M. 2002. Biological and medical significance of calcium phosphates. Angewandte Chemie International Edition, 41: 3130-3146.

Duncan, D.B. 1955. Multiple Range and Multiple F Tests. Biometrics, 11:1-42.

Eeckhout, W., de Paepe, M. 1994. Total phosphorus, phytate phosphorus and phytase activity in plant feedstuffs. Animal Feed Science and Technology, 47: 19-29.

Fernandez, S.R., Charraga, S., Avila-Gonzalez E. 2019. Evaluation of a new generation phytase on phytate phosphorus release for egg production and tibia strength in hens fed a corn-soybean meal diet. Poultry Science, 98: 2087-2093. doi:10.3382/ps/pey558
Gordon R., Roland Sr D. 1997. Performance of commercial laying hens fed various phosphorus levels, with and without supplemental phytase. Poultry Science, 76:1172-1177.

Ingelmann, C.J., Witzig, M., Mohring, J., Schollenberger, M., Kuhn, I., Rodehutscord, M. 2019. Phytate degradation and phosphorus digestibility in broilers and turkeys fed different corn sources with or without added phytase. Poultry Science, 98: 912-922, doi:10.3382/ps/pey438

Jalal M., Scheideler S. 2001. Effect of supplementation of two different sources of phytase on egg production parameters in laying hens and nutrient digestiblity. Poultry Science. 80: 1463-1471.

Kerovuo, J. 2000. A Novel Phytase from Bacillus. Characterization and Production of the Enzyme. Academic Dissertation, 68 p., Helsinki.

Keshavarz K. 2000. Nonphytate phosphorus requirement of laying hens with and without phytase on a phase feeding program. Poultry Science, 79: 748-763.

Kis, I., Gerendai, D., Gippert, T.(2000. The effect of phytase enzyme in the feeding of layers. Allattenyesztes es Takarmanyozas, 49:155-163.

Kubis, M., Lewko, L., Kaczmarek, S.A., Nowaczewski, S., Hejdysz, M., Rutkowski, A. 2019. The effect of enzyme and protein source on laying hens performance, eggshell and bone traits. Emirates Journal of Food and Agriculture, 31(5): 353-360 doi: 10.9755/ejfa.2019.v31.i5.1953.

Leyva-Jimenez, H., Alsadwi, A.M., Gardner, K., Voltura, E., Christopher, A., Bailey, C.A. 2019. Evaluation of high dietary phytase supplementation on performance, bone mineralization, and apparent ileal digestible energy of growing broilers. Poultry Science, 98:811-819, doi:10.3382/ps/pey389

Li, W., Angela, R., Kima, S.W., Jiménez-Morenoa, E., Proszkowiec-Weglarza, M., Plumstead, P.W. 2018. Impacts of age and calcium on Phytase efficacy in broiler chickens. Animal Feed Science and Technology, 238: 9-17, doi:10.1016/j.anifeedsci.2018.01.02129.

Liebert F., Htoo J., Sunder A. 2005. Performance and nutrient utilization of laying hens fed low-phosphorus corn-soybean and wheat-soybean diets supplemented with microbial phytase, Poultry Science, 84:1576-1583.

Lim, H., Namkung, H., Paik, I. 2003. Effects of phytase supplementation on the performance, egg quality, and phosphorous excretion of laying hens fed different levels of dietary calcium and nonphytate phosphorous. Poultry Science, 82:92-99.

Miller, S.C. 1992. Calcium homeostasis and mineral turnover in the laying hen. In Bone biology and skeletal disorders in poultry. Br. Poult. Sci., 23:103-116.

Mohamed E., El-Hack, A., Alagawany, M., Arif, M., Emam, M., Saeed M., Arain, M.A., Siyal, F.A., Patra, A., Elnesr, S.S., Khan R.U. 2018. The uses of microbial phytase as a feed additive in poultry nutrition. Ann. Anim. Sci., 18 (3): 639658, doi:10.2478/aoas-2018-0009

Musapuor, A., Pourreza, J., Samie, A., Moradi Shahrbabak H. 2005. The effects of phytase and different level of dietary calcium and phosphorous on phytate phosphorus utilization in laying hens. International Journal of Poultry Science, 4 (8): 560-562.

Pongmanee, K., Kühn, T., Korver, D.R. 2000. Effects of phytase supplementation on eggshell and bone quality, and phosphorus and calcium digestibility in laying hens from 25 to $37 \mathrm{wk}$ of age. Poultry Science, In press, doi: 10.1016/j.psj.2019.12.051

Sebastian S., Touchburn S., Chavez E., Lague P. 1996. The effects of supplemental microbial phytase on the performance and utilization of dietary calcium, phosphorus, copper, and zinc in broiler chickens fed corn-soybean diets. Poultry Science, 75:729-736. 
Selle, P.H., Ravindran, V. 2007. Microbial phytase in poultry nutrition. Animal Feed Science and Technology, 135:1-41.

Truong, H.H., Bold, R.M., Liu, S.Y., Selle, P.H. 2015. Standard phytase inclusion in maize based broiler diets enhances digestibility coefficients of starch, amino acids and sodium in four small intestinal segments and digestive Dynamics of starch and protein. Anim. Feed Sci. Technol., 209: 240-248, doi:10.1016/j. anifeedsci.2015.08.01257.
Wu G., Liu Z., Bryant M., Roland Sr D. 2006. Comparison of natuphos and phyzyme as phytase sources for commercial layers fed corn-soy diet. Poultry Science, 85: 64-69.

Zyla, K., Mika, M., Dulinski, R., Swiatkiewicz, S., Koreleski, J., Pustkowiak, H., Piironen, J. 2012. Effects of inositol, inositolgenerating phytase $\mathrm{B}$ applied alone, and in combination with 6phytase A to phosphorus-deficient diets on laying performance, eggshell quality, yolk cholesterol, and fatty acid deposition in laying hens. Poultry Science, 91:1915-1927, doi:10.3382/ps.2012-02198. 